\title{
PEMBUATAN SEDIAAN PAREM DARI KENCUR (Kaemferia galanga L) BERAS (Oriza sativa) DAN SERAI (Cymbopogon citratus)SEBAGAI PENYEMBUHAN LUKA MEMAR, BENGKAK DAN KESELEO
}

\author{
Linda Tamara $^{1}$, Susi Andriani ${ }^{2}$, Yusi Helmiawati ${ }^{3}$ \\ 1,2,3 Sekolah Tinggi Ilmu Kesehatan Holistik Purwakarta
}

\begin{abstract}
ABSTRAK
Latar belakang: Secara turun termurun rimpang kencur (Kaemferia galanga L) dikenal sebagai obat untuk menghilangkan rasa sakit gangguan otot. Masyarakat menggunakan rimpang kencur (kaemferia galanga $L$ ) dengan campuran beras (Oryza sativa) dan serai (Cymbopogoncitratus) yang kemudian dijadikan dalam satu ramuan obat luar dengan nama beras kencur instan, rimpang kencur secara empiris memiliki khasiat sebagai relaksan otot, sedangkan serai dapat berkhasiat sebagai obat sakit kepala, batuk, nyeri lambung, diare, penghangat badan, penurun panas dan pengusir nyamuk.

Tujuan: Penelitian ini bertujuan untuk menyediakan sediaan jadi ramuan tradisional yang dapat digunakan oleh masyarakat untuk pencegahan dan peningkatan kesehatan.

Metode: Penelitian ini merupakan penelitian deskriptif yang dikembangkan dari pengalaman turun-temurun mengenai khasiat dari kencur, beras dan serai untuk penyembuhan luka bengkak, memar dan keseleo pada kulit. Dalam penelitian ini peneliti membuat sediaan dari kencur (Kaemferia galanga L), beras (Oriza sativa) dan serai (Cymbopogon citratus) dalam bentuk parem keping melalui proses pengeringan selama 1 hari dengan menggunakan pelarut air. Parem dibuat dengan memasukan 100 gram simplisia dan 200 gram beras (Oriza sativa), air sebanyak $25 \mathrm{ml}$, parem yang didapat yaitu 100 gram dan menghasilkan 10 bulatan dengan masing-masing berat 10 gram.

Hasil: Pengujian organoleptis sediaan dilakukan selama 3 minggu dengan hasil yang menunjukan bahwa tidak ada perubahan negatif yang terjadi dari bentuk, warna, bau, rasa maupun pertumbuhan jamur.

Simpulan: Dalam penelitian ini peneliti berhasil membuat sediaan dalam bentuk parem keping yang dapat bertahan selama 3 minggu.
\end{abstract}

Kata kunci: Kencur, beras, serai, sediaan parem.

Korespondensi :

Susi Andriani

Program Studi D3 Farmasi, STIKes Holistic Purwakarta

J1. Veteran No.272 Ciseureuh Purwakarta, Jawa Barat 41118

Email : susi_andriani08@yahoo.co.id

Phone : 0857-2156-0088 


\title{
MAKING OF PREPARATIONS PAREM POWDER (Kaemferia galanga L) RICE (Oryza sativa) AND LEMONGRASS (Cymbopogon citratus) AS HEALING BRUISING, SWELLING AND SPRAINS
}

\begin{abstract}
Background:Kaemferia galanga $\mathrm{L}$ is known as a remedy for pain relief muscle disorders empirically. Kaemferia galanga $\mathrm{L}$ with Oryza sativa and Cymbopogon citratus can used in a medicinal herb. Kaemferia galanga $L$ has properties as a muscle relaxant, while lemongrass can be efficacious as a headache remedy, cough, stomach pain, diarrhea, body warmers, fever and mosquito repellent.

The aim: This research aim to provide the dosage of traditional herb that can be used by the community for the prevention and healt improvement.

Method: This research is a descriptive study that was developed from the experience of hereditary regarding the efficacy of kencur, rice and lemongrass for wound healing swelling, bruising and sprains to the skin. In this research, preparations of kencur (Kaemferia galanga L), rice (Oryza sativa) and lemongrass (Cymbopogon citratus) in the form parem puck through the process of drying for 1 day using water-soluble. Parem made by adding of 100 gram and 200 gram simplisia rice (Oryza sativa), $25 \mathrm{ml}$ of water, parem obtained are 100 grams and produces 10 each ringed with a weight of 10 grams.

Result: Tests organoleptic for 3 weeks with results showing that there is no negative changes from the shape, color, smell, taste and fungal growth. Conclusion: In this research managed to make preparations in the form parem pieces that can last for 3 weeks.
\end{abstract}

Keywords: Powder, Rice, lemongrass, preparations parem 


\section{PENDAHULUAN}

Warisan nusantara akan pengobatan tradisional yang sudah dilakukan oleh leluhur atau nenek moyang kita telah banyak dicontoh oleh masyarakat. Mereka memiliki kemampuan dalam mengolah tanaman keluarga menjadi salah satu bahan pengobatan. Masyarakat terbiasa menggunakan sediaan obat bahan alam dan semakin percaya manfaatnya bagi kesehatan. Disisi lain banyaknya dampak negatif penggunaan bahan-bahan sintetik menyebabkan kecenderungan masyarakat untuk kembali kebahan alam sebagai alternatif utama dalam pengobatan.

Masyarakat di daerah Subang, Jawa Barat, khususnya di Desa Rawameneng Kecamatan Blanakan, sampai saat ini masih mempertahankan tradisi nenek moyang dengan memanfaatkan tumbuhan disekitar rumah untuk pengobatan, walaupun sebenarnya sudah banyak pelayanan kesehatan didaerah tersebut, tetapi tidak sedikit masyarakat menggunakan tumbuhan untuk pengobatan. Dengan adanya tradisi tersebut maka penggunaan obat-obat tradisional semakin memudahkan masyarakat disana dalam melakukan pengobatan khususnya untuk dirinya sendiri dan keluarga. Obat tradisional adalah bahan atau ramuan bahan yang berupa bahan tumbuhan, hewan, mineral, sediaan sarian (galenik), atau campuran dari bahan tersebut yang secara turun temurun telah digunakan untuk pengobatan dan dapat diterapkan sesuai dengan norma yang berlaku di masyarakat ${ }^{1}$

Secara turun termurun rimpang kencur (Kaemferia galanga L) dikenal sebagai obat untuk menghilangkan rasa sakit gangguan otot. Setelah melakukan observasi dan beberapa wawancara pada masyarakat yang ada di Desa $\begin{array}{lllll}\text { Rawameneng Rt } & 07 & \text { Rw } & 01\end{array}$ Kecamatan Blanakan Kabupaten Subang sebanyak 20 orang dengan batasan usia 25 tahun sampai dengan 70 tahun dengan beragam macam pekerjaan, masyarakat disana menggunakan rimpang kencur (kaemferia galanga L) dengan campuran beras (Oryza sativa) dan 
serai (Cymbopogoncitratus) yang kemudian dijadikan dalam satu ramuan obat luar dengan nama beras kencur instan, rimpang kencur secara empiris memiliki khasiat sebagai relaksan otot, sedangkan serai dapat berkhasiat sebagai obat sakit kepala, batuk, nyeri lambung, diare, penghangat badan, penurun panas dan pengusir nyamuk ${ }^{2}$

Ketiga campuran dari rimpang kencur, serai dengan beras tersebut dapat dijadikan sebagai obat luka memar dan keseleo. Sediaan dari rimpang kencur yang sering digunakan oleh masyarakat Desa Rawameneng adalah sediaan ramuan instan yang langsung digunakan pada bagian kulit yang sakit, sedangkan sediaan ramuan instan hanya bisa bertahan sehari itu saja, banyak masyarakat yang belum mengetahui ramuan kencur yang bisa dijadikan sediaan seperti misalnya bedak, parem dan lain-lain.

Sediaan parem atau pilis adalah sediaan padat obat tradisional, yang bahan bakunya berupa serbuk simplisia, sediaan galenik, atau campurannya dan digunakan sebagai obat luar ${ }^{3}$ Berdasarkan latar belakang diatas, maka penulis tertarik untuk melakukan penelitian dengan judul "Pembuatan Sediaan Parem dari Kencur (Kaemferia galanga $L$ ) dengan Beras (Oryza sativa) dan Serai (Cymbopogon citratus) Sebagai Penyembuhan Luka Memar Bengkak dan Keseleo ". Pada pembuatan sediaan parem ini, diharapkan dapat memberikan informasi mengenai kemampuan kencur sebagai obat luar untuk mengobati luka memar atau keseleo, yang hingga kini masih belum banyak diketahui oleh masyarakat.

\section{METODE PENELITIAN}

Penelitian ini menggunakan metode penelitian deskriptif yaitu penelitian yang dilakukan untuk menggambarkan karakteristik suatu kelompok subyek tertentu ${ }^{4}$. Pengumpulan data dilakukan dengan cara wawancara terhadap masyarakat setempat, selain itu dilakukan juga studi literatur. Penelitian dengan metode wawancara dimaksudkan untuk mengetahui seberapa luas 
masyarakat mengenal tumbuhan sebagai bahan obat, dalam hal ini sebagai nara sumber adalah beberapa masyarakat yang pernah menggunakan tumbuhan kencur, beras dan serai sebagai bahan obat tradisional dan bagaimana masyarakat tersebut membuat ramuannya. Jenis tumbuhan yang akan dibuat adalah sediaan parem yaitu dari tumbuhan Rimpang kencur (Kaemferia galanga L), beras (Oryza sativa) dan serai (Cymbopogon citratus). Ada beberapa tahapan seperti pengumpulan bahan, penyiapan bahan yang bagus untuk dijadikan obat ramuan, dan pembuatan sediaan menjadi parem ${ }^{5}$.

Subyek dalam penelitian ini adalah orang dewasa berjumlah 20 orang dengan usia 30 sampai 70 tahun dengan beragam pekerjaan. Penyiapan bahan-bahan yang berdasarkan hasil wawancara adalah rimpang kencur dikumpulkan dengan jumlah yang sudah ditentukan yaitu 50 gram, dibersihkan dari kotoran, dicuci setelah itu ditiriskan begitu juga dengan serai sebanyak 50 gram, sedangkan beras sebanyak 200 gram dilakukan perendaman dengan air selama tiga jam. Rimpang kencur yang sudah bersih di rajang bersama serai kemudian ditumbuk bersamaan, setelah halus dicampur dengan beras yang sudah direndam kemudian tumbuk sampai halus.

Lokasi penelitian dipilih Desa $\begin{array}{lllll}\text { Rawameneng } & \mathrm{Rt} & 07 & \mathrm{Rw} & 01\end{array}$ kecamatan Blanakan kabupaten Subang, alasan peneliti memilih tempat Desa Rawameneng Kecamatan Blanakan Kabupaten Subang karena di daerah tersebut masih banyak terdapat masyarakat yang menggunakan tumbuhan tradisional sebagai obat, selain itu pengobatan tradisional merupakan upaya penyembuhan terhadap penyakit yang dilakukan berdasarkan kepercayaan secara turun temurun dengan menggunakan bahan alami yang tersedia dan mempunyai khasiat secara empiris maupun melalui perantara seseorang ( paraji atau dukun ), walaupun pengobatan modern telah banyak didaerah tersebut namun hingga sekarang pengobatan dengan bahan alam masih tetap dipertahankan, peneliti 
juga ingin memperkenalkan kepada masyarakat lain tentang khasiat ramuan beras kencur serai sebagai obat untuk memar dan keseleo.

\section{HASIL PENELITIAN}

\section{Hasil dari wawancara}

Pada penelitian ini dilakukan wawancara sebanyak 20 orang di Desa Rawameneng, Kecamatan Blanakan, Kabupaten Subang, yang bertujuan untuk mengetahui apakah benar parem beras kencur dan serai digunakan sebagai pengobatan bengkak, memar dan keseleo dan bagaimana pemilihan bahan baku yang baik. Pemilihan bahan baku yang baik yaitu :

\section{Kencur yang digunakan} dalam penelitian ini diperoleh dari perkebunan di Kecamatan Desa Blanakan Kabupaten Subang dipilih kencur yang berumur 6 bulan, menunjukan kencur sudah siap dipanen.

Beras putih yang digunakan diperoleh dari padi yang berasal dari Blanakan, pemilihan beras dilihat dari warna beras yang tidak mengandung pemutih yaitu berwarna bening sedikit kekuningan.

Serai yang digunakan adalah serai dapur yang diperoleh dari Cilamaya karawang. Serai diambil batangnya, pemilihannya dengan memilih batang serai yang tidak rusak.

Berdasarkan hasil yang diperoleh menunjukan bahwa tumbuhan yang diambil dari Desa Blanakan dan Desa Cilamaya yaitu tumbuhan kencur, beras dan serai yang segar diambil dari perkebunan untuk membuat sediaan ramuan harus menggunakan pemilihan bahan yang bagus.

Setelah pemilihan bahan baku, dilakukan wawancara tentang khasiat sediaaan parem yang pernah di buat ibu $\mathrm{N}$ sebagai paraji yang berusia 60 tahun pernah membuat tumbukan ramuan beras kencur dengan campuran serai untuk seorang ibu setelah melahirkan dengan kondisi kaki yang bengkak disertai memar diperoleh hasil wawancara seperti berikut : 
Pertanyaan: Tumbuhan apa saja yang digunakan masyarakat di desa ini untukmengobati bengkak dan keseleo ?

Jawaban informan: Sering membuat campuran dari beras, kencur dan serai untukgangguan otot dan paling sering digunakan untuk wanita setelah melahirkan karena bisa mengobati bengkak dan memar.

Parem kencur beras dan serai dibuat di desa Rawameneng Kecamatan Blanakan Subang dengan didampingi warga yang sudah diwawancarai dan di dapat hasil wawancara yang menerangkan bahwa bahan-bahan untuk pembuatan parem adalah kencur, beras dan serai.

Dari hasil wawancara yang telah dilalukan 2 orang mengatakan bahwa sediaan parem dari beras, kencur dan serai sebagai obat sakit leher (gangguan otot), 7 orang mengatakan bisa mengobati pegalpegal dan 8 orang mengatakan keseleo, sedangkan 12 mengatakan untuk bengkak, dan 12 orang juga mengatakan sediaan parem dari beras kencur dan serai bisa mengurangi memar.

Tabel 1. Hasil wawancara khasiat penggunaan parem dari beras,kencur dan serai

\begin{tabular}{ll}
\hline Macam gangguan & Hasil pengamatan \\
\hline Memar & 12 orang \\
Bengkak & 12 orang \\
Keseleo & 8 orang \\
Pegal-pegal & 7 orang \\
Sakit leher & 2 orang \\
\hline
\end{tabular}


Hasil wawancara yang

dilakukan menunjukan parem dari beras, kencur dengan dan serai paling sering digunakan masyarakat untuk penyembuhan bengkak, keseleo dan pegal.

\section{Hasil sediaan}

Dari beras sebanyak 200 gram, kencur 50 gram dan serai 50 gram didapat hasil yang sudah dikeringkan yaitu sebanyak 100 gram dibuat 10 keping parem dengan masing-masing berat per 1 keping parem yaitu 10 gram.

Tabel 2. Sediaan pertama jadi

\title{
Gambar sediaan pertama jadi Keterangan
}

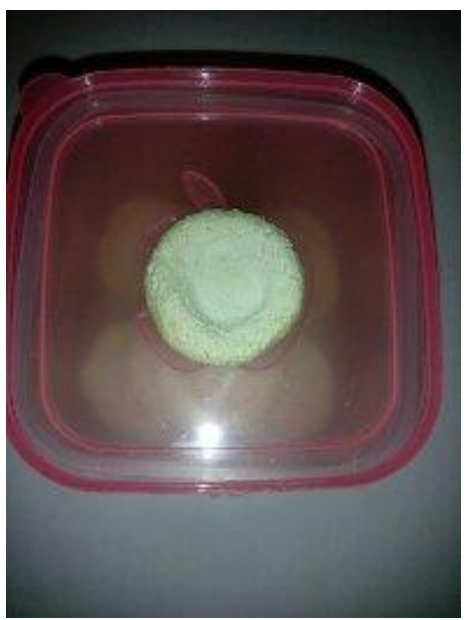

\author{
Warna : Putih, sedikit kuning \\ Bau : Khas kencur dan serai \\ Bentuk : Perem jika diencerkan \\ dan dipegang dengan tangan \\ yang basah memiliki rasa sangat \\ hangat pada kulit
}

\section{PEMBAHASAN}

Dari hasil penelitian, pembuatan parem dari kencur, beras dan serai membutuhkan waktu selama dua hari yaitu penyiapan bahan dan proses pengeringan selama satu hari.
Dari hasil sediaan selama tiga minggu dan di uji secara organoleptis, hasilevaluasi sediaan yang sudah jadi yaitu sediaan berbentuk seperti kepingan uang logam, dengan warna putih kekuning-kuningan dengan bau khas kencur yang menyebar pada parem, 
bisa dirasakan dengan cara parem di pegang dengan tangan yang basah bisa menimbulkan rasa hangat, dan dari hasil wawancara, parem bisa meringankan rasa sakit sedangkan khasiat serai untuk menghangatkan badan $^{2}$, maka kencur juga menunjukan hasil pada sediaan karena dari khasiatnya kencur bisa menyembuhkan luka. Setelah tiga minggu sediaan disimpan sediaan masih berbau kencur dan serai menunjukan sediaan tidak berubah pada rasa, warna berubah menjadi sedikit kuning hanya saja parem berkurang hangatnya sedikit.

Tabel 3. Sediaan setelah 3 minggu

\begin{tabular}{llll}
\hline Sediaan setelah 3 minggu & Keterangan & \\
\hline Bau & $:$ & Putih Kekuningan \\
Bentuk & $:$ & Parem jika diencerkan \\
& & $\begin{array}{l}\text { menimbulkan rasa hangat } \\
\text { pada kulit. }\end{array}$ \\
& & \\
& & \\
\hline
\end{tabular}

Pengunaan sediaan parem dari beras kencur dan serai caranya dengan mengambil satu keping parem dilarutkan dengan air secukupnya dan balurkan kebagian yang sakit, tunggu sampai kering atau kurang lebih 20 menit lalu basuh dengan air bersih atau air hangat.

\section{SIMPULAN}

$\begin{array}{rrr}\text { Hasil } & \text { penelitian } & \text { ini } \\ \text { menunjukan } & \text { bahwa di } & \text { Desa }\end{array}$

\begin{abstract}
Rawameneng Kecamatan Blanakan Kabupaten Subang pada 20 orang sebagaiinformasinya,diperoleh hasil wawancara tentang pembuatan sediaan parem untuk obat luar yang dibuat secara sederhana yaitu pencampuran kencur, beras dan serai diblender sampai menjadi adonan seperti pasta lalu dibentuk menjadi kepingan kecil dan dijemur selama satu hari.
\end{abstract}


Berdasarkan penelitian yang telah dilakukan, bahan herbal yang digunakan untuk antiinflamasi adalah minyak kencur dan pada penelitian ini, rimpang kencur terbukti dapat dapat diolah menjadi suatu bentuk sediaan yang dikombinasikan dengan serai dan beras yang dapat digunakan untuk penyembuahan luka memar, bengkak dan keseleo pada kulit ${ }^{6}$.

Sediaan dari kencur, beras dan serai berhasil dibuat dalam bentuk parem keping dan dapat bertahan selama tiga minggu, tanpa ada perubahan dalam bentuk, bau, warna maupun timbulnya jamur dikarenakan proses pengeringan selama satu hari dan di cek secara berkala.

\section{DAFTAR PUSTAKA}

1. Permenkes RI No.007 Tahun 2012. Registrasi Obat Tradisional

2. Fauzi. Pemanfaatan Tumbuhan Serai WangiI (Cymbopogon nardus (L.) Rendle) Sebagai Antioksidan Alami. Samarinda: Jurusan kimia FMIPA; 2009.

3. Menkes no.661/sk/VII/1994. Proses Pengolahan Jamu Sediaan Kapsul.

4. Badan Pengawas Obat Dan Makanan Republik Indonesia. Pedoman Cara Pembuatan Simplisia Yang Baik. Jakarta: BPOM; 2012.

5. Hendriati et al. Pengaruh Pemacu Transpor Terhadap Aktivitas Anti Inflamasi Minyak Kencur ( Kaempferia Galanga L ). Jurnal Bahan Alam Indonesia. 2010; 7: 5-6. 